Канд. екон. наук О.В. Дикань, Т.М. Давидова

\title{
ОРГАНІЗАЦІЙНО-МЕТОДИЧНЕ ЗАБЕЗПЕЧЕННЯ ПРОФЕСІЙНОӤ ПІДГОТОВКИ СПЕЦІАЛІСТІВ ТРАНСПОРТУ
}

\author{
Представив д-р екон. наук, професор О.Г. Дейнека
}

Постановка проблеми. У даний час у системі професійної підготовки фахівців в Україні спостерігаються істотні зміни, зумовлені ऑii функціонуванням у новій економічній формації, світовими тенденціями у сфері освіти, процесом модернізації російської освіти. Ключовим принципом удосконалення професійної підготовки фахівців у якісному аспекті $\epsilon$ орієнтація на вимоги споживачів освітніх послуг. Даний принцип означає, що конкурентоспроможність спеціаліста (випускника вишу) на ринку праці зумовлюється відповідністю результатів його професійної підготовки вимогам роботодавців. Необхідна умова підвищення конкурентоспроможності випускників вишу - реалізація практикоорієнтованого підходу при їх підготовці.

Посилення практичної спрямованості підготовки фахівців - пріоритетне завдання кадрового забезпечення транспортної галузі в умовах реформування. Світова фінансова криза, посилення конкуренції на ринку вантажних i пасажирських перевезень загострили потребу підприємств транспорту у фахівцях, здатних працювати у швидко мінливих економічних умовах, i посилили вимоги до якості професійної підготовки кадрів. 
Вищесказане визначає актуальність розроблення організаційно-методичного забезпечення професійної підготовки фахівців транспорту, спрямованого на розвиток у процесі навчання затребуваних у практичній діяльності характеристик фахівця, проведення оцінки сформованих у нього якостей і забезпечення підбору для фахівця робочого місця, відповідного його виявленим якостям.

Аналіз останніх досліджень i публікацій. Вивченню теоретичних аспектів підготовки якісних фахівців присвячені праці В.А. Антропова, О.Г. Берестнєва, О.В. Марухіна, А.П. Єгоршина, Є.М. Савіної, Н.А. Селезньової та ін. Однак у роботах зазначених авторів недостатньо уваги приділено реалізації практикоорієнтованого підходу при підготовці фахівців, а також комплексній оцінці результатів підготовки фахівців на відповідність вимогам роботодавців.

Вивченням і систематизацією сучасних вимог до підготовки фахівців 3 вищою професійною освітою займалися такі вчені як B.I. Байденко, Ю.С. Васильєва, В.В. Глухова, Є.Б. Куркіна, А.М. Новікова, C.I. Сотникова, М.П. Федорова, які розглядають питання підготовки фахівців у зв'язку 3 глобалізацією економічного простору, розвитком ринкових принципів економіки в нашій країні, реформуванням європейської і модернізацією української освіти.

Виділення невирішених частин загальної проблеми. У науковій літературі проблема підготовки фахівців відповідно до потреб ринку праці зв'язується 3 реалізацією компетентнісного підходу. Разом 3 тим організаційно-методичного забезпечення потребують питання вивчення та формалізації складу компетенцій фахівця, що забезпечують ефективне виконання посадових обов'язків у певній сфері професійної діяльності з урахуванням конкретної галузевої специфіки, розроблення механізму їх формування, а також проведення оцінки результатів підготовки фахівців на відповідність вимогам, що висуваються галузевим ринком праці. Невирішеність перелічених питань визначила постановку мети i завдань дослідження, об'єкта і предмета.

Формування цілей статті. Метою даної статті $\epsilon$ розгляд механізму організаційно-методичного забезпечення професійної підготовки фахівців транспорту.

Виклад основного матеріалу дослідження й обгрунтовування одержаних наукових результатів. Вивчення трансформації сучасних зарубіжних i вітчизняних вимог до підготовки фахівців з вищою професійною освітою, що містяться в науковій літературі, дало змогу як основний напрямок розроблення організаційнометодичного забезпечення професійної підготовки фахівців для підприємств транспорту використати реалізацію практикоорієнтованого підходу, що враховує вимоги роботодавців та забезпечує підбір для фахівця робочого місця відповідно до його виявлених якостей.

В умовах глобалізації, функціонування ринкової економіки український ринок праці характеризується посиленням конкуренції серед фахівців управлінського та економічного профілю, підвищенням інтенсивності та продуктивності їх праці, зростанням самостійності, активності при пошуці роботи. Зміни, що відбуваються на ринку праці, зумовили розширення вимог до фахівців. Огляд наукової літератури та нормативних документів дозволяє виявити затребуваність на ринку праці додаткових характеристик фахівця. Головними ресурсами розвитку інноваційної економіки $\epsilon$ мотивація, креативність, інтерес. Тобто в нових економічних умовах на перший план виходить вмотивованість працівника до ефективної і творчої праці. 
Реформування транспортної галузі істотно впливає на трансформацію вимог до складу якостей фахівця. У літературі зазначається потреба підприємств залізничного транспорту у фахівцях нового типу, здатних у повному обсязі реалізувати свій трудовий потенціал, і керівниках, які вміють працювати в нових економічних умовах, швидко реагують на зміни технічного і технологічного процесів, які не бояться брати відповідальність за прийняті рішення.

$\begin{array}{crrr}\text { У даний } & \text { час } & \text { при } & \text { формуванні } \\ \text { кадрового } & \text { складу } & \text { транспортних }\end{array}$ підприємств недостатньо інформації про вимоги до працівника, щоб розробити перелік характеристик, затребуваних у галузі. Відбувається розширення вимог до складу характеристик працівника в плані наявності не тільки певного рівня кваліфікації (освіта, досвід роботи тощо), але i поведінкових характеристик, що відображають його мотиваційний стан.

Таким чином, зміна та розширення вимог до фахівців (у тому числі випускників вишу) 3 боку виробничої сфери характеризується тим, що, крім традиційних вимог до працівника, що полягають у наявності освіти та рівня кваліфікації, спостерігається тенденція посилення ролі поведінкових характеристик індивіда в ефективній трудовій діяльності.

Вивчення вживаних у даний час для визначення вимог до працівників професіограм і моделей фахівця показує, що в їх основі закладено кваліфікаційний підхід, який у сфері освіти отримав назву «знаннєвого» (ЗУН - знання, уміння, навички). $\mathrm{y}$ цілому поданий $\mathrm{y}$ професіограмі і моделі фахівця склад показників працівника відображає вимоги до здатності індивіда виконувати функцію певної складності і приймати рішення в певній галузі діяльності. Кваліфікаційний погляд припускає проведення психофізіологічних досліджень якостей індивіда й орієнтований на виявлення потенційних характеристик працівника. Однак фактичний прояв якостей працівника зумовлений мотиваційним станом індивіда, якістю зовнішньої мотивації і може істотно відрізнятися від характеристик, отриманих у результаті психофізіологічних досліджень. Для прояву потенційних якостей вимагається збіг ціннісних характеристик працівника i пріоритетів мотиваційної системи організації. У зв'язку 3 цим поряд 3 дослідженням потенціалу індивіда потрібні вивчення та оцінка якостей працівника, що фактично проявляються, характеристик, які дають змогу найбільш точно прогнозувати ефективність його трудової діяльності.

Узагальнення точок зору щодо компетентнісного підходу й авторське бачення проблеми дозволили нам виділити i сформулювати три принципові особливості компетентнісного підходу в порівнянні 3 кваліфікаційним стосовно професійної підготовки фахівців:

- у кваліфікаційному підході акцент робиться на накопичення знань, умінь, навичок, а в компетентнісному підході кількість якісних характеристик розширюється. Останнім часом виділяються здатність і готовність людини реалізовувати свій потенціал у практичній діяльності (вирішення реальних завдань, проблемних ситуацій). Під здатністю розуміється наявність у працівника професійних характеристик (знання, уміння, навички), відповідних конкретній сфері трудової діяльності. Однак характеристика «готовність» не має чіткого визначення. Нами пропонується конкретизувати поняття «Готовність» i визначити його як необхідний для ефективного виконання посадових обов'язків мотиваційний стан працівника, що припускає відповідну трудову поведінку. Потребою виробничої сфери обумовлена актуалізація вивчення та оцінки мотиваційного стану працівника до ефективної трудової діяльності, які 
пропонується здійснювати під час реалізації компетентнісного підходу;

- компетентнісний підхід передбачає значне посилення практичної спрямованості підготовки фахівців. Компетентнісний підхід дає змогу не тільки враховувати i реалізовувати в процесі підготовки затребуваний в організаціях комплекс характеристик фахівця, але гнучко і своєчасно адаптувати підготовку фахівців під мінливі умови зовнішнього середовища, що не достатньо реалізовувалося при кваліфікаційному підході;

- кваліфікаційний підхід орієнтований на вивчення і вимір потенційних характеристик працівника. Проте практична діяльність показує, що потенційні характеристики працівника, не знаходячи виходу i підтримки iз зовнішнього середовища у вигляді реальних умов для іiі втілення в життя, можуть залишитися тільки потенціалом людини. У нашому баченні в рамках компетентнісного підходу у відповідності до потреб виробничої сфери повинні вивчатися і оцінюватися не тільки потенційні (що характерно для кваліфікаційного підходу), а й фактично притаманні якості індивіда.

Таким чином, вивчення сутності дуже поширеного кваліфікаційного погляду на склад показників працівника не дозволяє визнати його таким, що відповідає сучасним вимогам практичної діяльності, у зв'язку з чим дано додаткове обгрунтування необхідності переходу від кваліфікаційного до компетентнісного підходу стосовно підготовки фахівців.

3 урахуванням висновків про затребуваність у практичній діяльності розширеного складу якостей фахівця необхідно виділити поряд 3 групою функціональних (характеризують здатність працівника застосовувати знання, уміння та навички у трудовій діяльності) групу поведінкових (характеризують вмотивованість індивіда до ефективного виконання

посадових

обов'язків)

компетенцій.

Необхідність виділення двох груп компетенцій фахівця викликана існуючими проблемами трудової мотивації персоналу організацій. Так, у працівника може бути високий рівень функціональної компетентності, але якщо у нього слабка мотивація до праці, що виражається в низькому рівні поведінкової компетентності, то результати його роботи не будуть високими. На практиці роботодавці все частіше віддають перевагу працівникові, що демонструє відповідальність, інтерес, бажання працювати, так як він може досягти багато чого, навіть не володіючи на початковому етапі високим рівнем функціональної компетентності. Своєчасна актуалізація поведінкової складової до цих пір не знайшла повного відображення в кадровій роботі організацій i практично не враховується при професійній підготовці фахівців.

Проведення комплексної оцінки компетентності майбутніх менеджерів має проходити 3 боку різних споживачів освітніх послуг: держави, потенційних роботодавців, самих студентів. Основним інструментом для проведення процедури оцінки компетентності фахівця повинні служити розроблені паспорти фахівця.

Під час практичних дій проявляється компетентність майбутнього фахівця, демонструються різні якості при вирішенні навчальних i виробничих завдань, при спілкуванні з викладачами, керівниками та колегами. За висновками психологів поведінкові характеристики індивіда досить стійкі протягом життя. Звідси випливає, що результати практичної діяльності випускника вишу дозволяють 3 високим ступенем точності спрогнозувати ймовірність прояву тих чи інших якостей у реальній трудовій діяльності, а, отже, і ефективність його праці в певній професійній сфері. Якщо він показав себе ініціативною, творчою, відповідальною, 
працьовитою людиною, то і в майбутній трудовій діяльності при створенні відповідних умов можна очікувати від нього прояву тих же якостей.

Для мінімізації виявлених слабких сторін необхідно розробити низку напрямів у підготовці менеджерів: розвиток взаємин вишу 3 підприємствами транспорту; посилення уваги до галузі формування поведінкових характеристик майбутніх фахівців; підвищення якості практичної підготовки студентів, у тому числі під час виробничих та переддипломної практик; розширення використання в навчальному процесі активних методів навчання, особливо пов'язаних з груповою роботою і презентацією рішень ділових завдань i ситуацій; розвиток дослідницької роботи студентів.

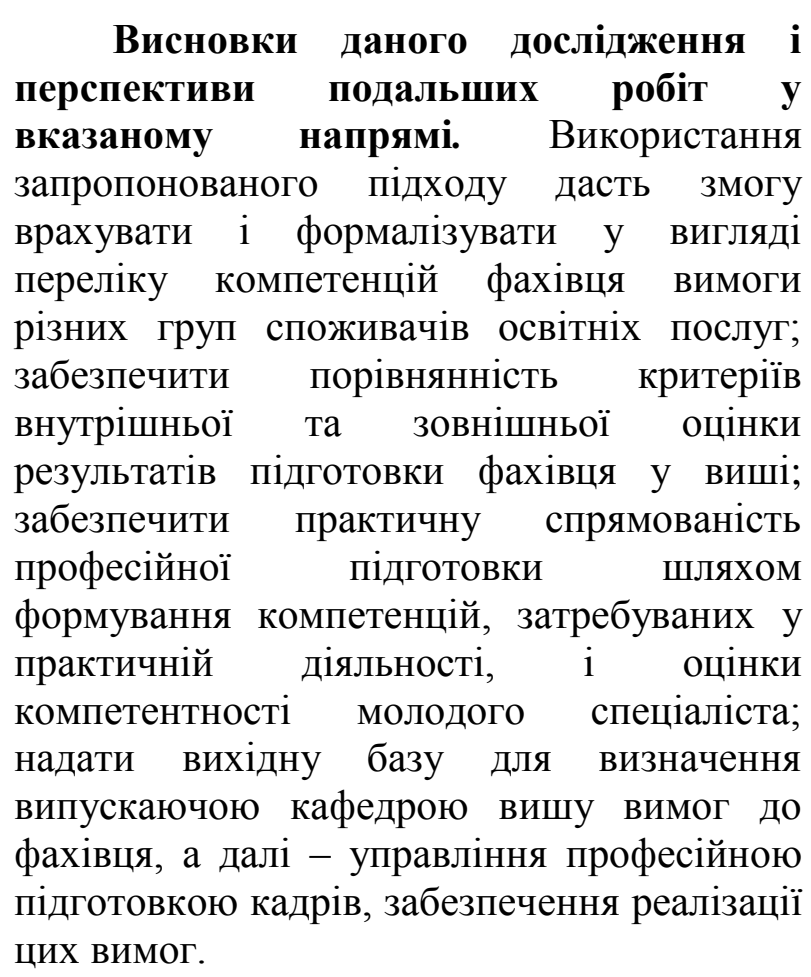

\section{Список літератури}

1. Ансофф, И. Стратегическое управление [Текст] / И. Ансофф. - М.: Экономика, 1989. $-519 \mathrm{c}$.

2. Заярна, Н.М. Проблеми і перспективи розвитку трудових ресурсів в Україні [Текст] / Н.М. Заярна, О.М. Каралюс // Науковий вісник НЛТУ України: зб. наук.-техн. праць. - Львів: РВВ НЛТУ України, 2011. - Вип. 21.3. - С. 172-175.

3. Державина, И.А. Современный рынок образовательных услуг: подготовка специалистов в сфере инноваций [Текст] / И.А. Державина // Менеджмент инноваций. 2008. - № 3. - C. 34-38.

Ключові слова: система управління персоналом, професійна освіта, компетентності персоналу, особливості підготовки залізничників.

\section{Анотації}

Стаття присвячена проблемам розвитку професійних компетенцій персоналу транспортних підприємств. Розглядаються питання комплексної оцінки компетентності майбутніх менеджерів, виділяються професійні та функціональні компетентності.

Статья посвящена проблемам развития профессиональных компетенций персонала транспортных предприятий. Рассматриваются вопросы комплексной оценки компетентности будущих менеджеров, выделяются профессиональные и функциональные компетентности.

The article deals with problems of professional competence of the personnel of transport companies. Questions of a comprehensive assessment of competence of future managers, professional and functional stand competence. 